\title{
Effects of Long-Term Haloperidol Treatment on the Responsiveness of Accumbens Neurons to Cholecystokinin and Dopamine: Electrophysiological and Radioligand Binding Studies in the Rat
}

\author{
Guy Debonnel, ${ }^{1,4}$ Pierrette Gaudreau, ${ }^{2}$ Rémi Quirion, ${ }^{3,4}$ and Claude de Montigny ${ }^{4}$ \\ IInstitut Philippe Pinel de Montréal, ${ }^{2}$ Notre-Dame Hospital, Montréal, ${ }^{3}$ Douglas Hospital, Verdun, and ${ }^{4}$ Department of \\ Psychiatry, McGill University, Montreal, Quebec, Canada, H3A 1A1
}

\begin{abstract}
Cholecystokinin (CCK) and dopamine (DA) coexist in a subpopulation of neurons of the ventral tegmental area projecting to the nucleus accumbens. The present experiments were undertaken to determine the effect of acute and longterm administration of haloperidol on the responsiveness of accumbens neurons to microiontophoretic applications of the sulfated cholecystokinin octapeptide (CCK-8S), kainate (KA), and DA and on the density of CCK, D1, and D2 receptors determined by radioautography. Acute administration of haloperidol ( $1 \mathrm{mg} / \mathrm{kg}$, i.v.) did not modify the neuronal responsiveness to DA and KA but increased that to CCK-8S. Long-term treatment with haloperidol decanoate $(4 \mathrm{mg} / \mathrm{kg} /$ week, i.m., for 3-5 weeks) induced a marked increase in the responsiveness to CCK-8S, without noticeable change of that to DA and KA. After a 5 week treatment, significant increases in the amounts of CCK and D2 binding were found in the nucleus accumbens, whereas D1 binding parameters remained unchanged. Since long-term haloperidol treatment results in a depolarization inactivation of $\mathbf{A} 10$ dopaminergic neurons, these results suggest that, despite the reduced firing activity of mesolimbic dopaminergic neurons induced by the long-term haloperidol treatment, dopamine is still released in an amount sufficient to maintain a normal neuronal responsiveness of postsynaptic accumbens neurons to DA, whereas the release of CCK is possibly decreased to a greater extent, resulting in an enhanced responsiveness of the neurons to this peptide.
\end{abstract}

Cholecystokinin (CCK), particularly in its 8-sulfated form (CCK$8 \mathrm{~S}$ ), is found in high concentrations in the mammalian brain, where it may act as a neurotransmitter or a neuromodulator (Vanderhaegen et al., 1975; Dockray, 1976; Rehfeld, 1978; Barden et al., 1981; Beinfeld et al., 1981; Fredens et al., 1984). CCK binds to 2 types of receptors (Hays et al., 1980; Saito et al., 1980; Praissman et al., 1983; Zarbin et al., 1983; Van Dijk

\footnotetext{
Received Jan. 25, 1989; revised July 24, 1989; accepted July 26, 1989.

This work was supported, in part, by the Medical Research Council of Canada, the Fonds de la Recherche en Santé du Québec (FRSQ), and the Parkinson Foundation of Canada. G.D. was in reccipt of a Fellowship from the Institut PhilippePinel de Montréal, R.Q. and P.G. were in receipt of a scholarship from the FRSQ.

We thank L. Caillé for computer programming and statistical analysis. G. Filosi and $G$. Lambert for preparing the illustrations, and H. Cameron and S. Green for secretarial assistance.

Correspondence should be addressed to Dr. Guy Debonnel, Department of Psychiatry, McGill University, 1033 Pine Avenue West, Montreal, Quebec, Canada $\mathrm{H} 3 \mathrm{~A} 1 \mathrm{Al}$

Copyright $(1990$ Society for Neuroscience $0270-6474 / 90 / 100469-10 \$ 02.00 / 0$
}

et al., 1984; Gaudreau et al., 1985; Lin and Miller, 1985; Mantyh and Mantyh, 1985; Pélaprat et al., 1985; Quirion et al., 1985; Wennogle et al., 1985; Clark et al., 1986; Sekiguchi and Moroji, 1986; Dietl et al., 1987). The first type, denoted type A, appears to be confined to the area postrema, the interpeduncular nucleus, the nucleus tractus solitarius, and the nucleus accumbens and possess a pharmacological profile similar to that of peripheral CCK receptor (Moran et al., 1986; Hill et al., 1987a, b; Vickroy et al., 1988) The second type, denoted type B, is widely distributed (Moran et al., 1986) and different from those found in the pancrcas (Innis and Snyder, 1980). In most regions of the CNS, CCK-8S increases the neuronal firing activity when applied microiontophoretically or injected intravenously (Dodd and Kelly, 1981; Skirboll et al., 1981; Bunney et al., 1982; Rogawski, 1982; Morin et al., 1983; Crawley et al., 1984; DeFrance et al., 1984; White and Wang, 1984; Hommer et al., 1985; Wang and Hu, 1986; Chiodo et al., 1987; Freeman and Bunney, 1987; Debonnel and de Montigny, 1988).

Immunohistochemical studies and retrograde tracing have shown that CCK is present in a subpopulation of dopaminergic neurons of the ventral tegmental area (VTA) projecting to limbic areas and particularly to the caudodorsomedial part of the nucleus accumbens (Hökfelt et al., 1980a, b; Gilles et al., 1983). Lesioning of the VTA or of the medial forebrain bundle has been reported to decrease the CCK content in the nucleus accumbens (Studler et al., 1981; Marley et al., 1982; Gilles et al., 1983 ) and to increase the binding of CCK and dopamine (DA) (Chang et al., 1983). In keeping with these data, lesioning of VTA dopaminergic neurons with 6-hydroxydopamine increases the responsiveness of accumbens neurons to both CCK-8S and DA (Debonnel and de Montigny, 1988).

Since long-term treatment with neuroleptics induces a depolarization block of $\mathrm{A} 9$ and $\mathrm{A} 10$ dopaminergic neurons (Bunney and Grace, 1978; Chiodo and Bunney, 1983; White and Wang, 1983; Grace and Bunney, 1986), and since this suppression of the firing activity of mesolimbic dopaminergic neurons could play a role in the antipsychotic activity of neuroleptics, it appeared interesting to study electrophysiologically the in vivo responsiveness of accumbens neurons to $\mathrm{CCK}-8 \mathrm{~S}$ and $\mathrm{DA}$ in rats treated acutely or chronically with haloperidol and to evaluate possible changes in CCK, D1, and D2 receptor binding using quantitative radioautography.

\section{Materials and Methods}

\section{Haloperidol treatments}

In a first series of experiments, male Sprague-Dawley rats weighing 200$225 \mathrm{gm}$ were administered intravenously $1 \mathrm{mg} / \mathrm{kg}$ of haloperidol (McNeil, 
Table 1. Effect of sulfated cholecystokinin 26-33 (CCK) applied microiontophoretically onto nucleus accumbens neurons in control rats and in rats treated with long-term haloperidol

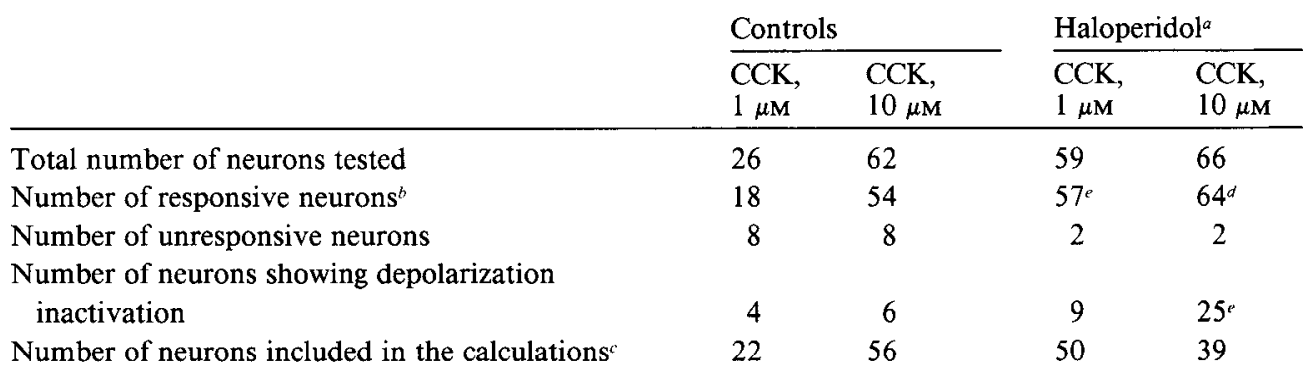

${ }^{a}$ Experiments were carried out after 3 or 5 weeks of treatment with long-acting haloperidol decanoate $(4 \mathrm{mg} / \mathrm{kg}, \mathrm{i} . \mathrm{m}$., once a week).

"This number includes the neurons showing a depolarization inactivation upon CCK application.

c This number includes all neurons recorded minus those having presented a depolarization inactivation. The 3 and 5 wcck haloperidol trcatments werc pooled.

${ }^{d} p<0.05$.

$c p<0.001$ compared with corresponding control value $\left(\chi^{2}\right.$ test $)$.

Stoufville, Ontario) injected via a femoral catheter. In a second series of experiments, rats were injected once a week, intramuscularly with 4 $\mathrm{mg} / \mathrm{kg}$ of the long-acting haloperidol decanoate (McNeil) for 3 or 5 weeks. A second group of rats was housed in the same conditions for the same period. These animals were used as controls for the electrophysiological and the radioligand binding studies. During this period, treated and control rats were kept in a light: dark cycle 12:12 $\mathrm{hr}$ with free access to food and water.

\section{Electrophysiological experiments}

Preparation and microiontophoresis. Rats were anesthetized with urethane $(1.25 \mathrm{gm} / \mathrm{kg}$, i.p.) and mounted in a stereotaxic apparatus. Fivebarreled glass micropipettes, prepared in a conventional manner (Haigler and Aghajanian, 1974), were used for extracellular recordings and microiontophoretic applications; their tips were broken back, under microscopic control, to an 8-10 $\mu \mathrm{m}$ diameter. The central harrel used for unitary recording was filled with a $2 \mathrm{M} \mathrm{NaCl}$ solution saturated with fast green FCF. One side barrel, used for automatic current balancing, was filled with a $2 \mathrm{M} \mathrm{NaCl}$ solution. The remaining barrels were filled with the following solutions: DA, $0.1 \mathrm{M}, \mathrm{pH} 5$ (Aldrich, Milwaukee, WI); CCK-8S, 1 or $10 \mu \mathrm{M}$ in $200 \mathrm{~mm} \mathrm{NaCl}$ (Sigma, St. Louis, MO), pH 5; kainate (KA) $1 \mathrm{~mm}$ in $400 \mathrm{~mm} \mathrm{NaCl}, \mathrm{pH} 8$ (Sigma). Recordings were obtained in the caudodorsomedial part of the nucleus accumbens, in an area defined stereotaxically as $9.5-11 \mathrm{~mm}$ anterior to lambda, $0.8-$ $1.5 \mathrm{~mm}$ lateral to the midline, and $5.5-6.5 \mathrm{~mm}$ below the cortical surface. The ventral limit of the nucleus accumbens was localized by the large-amplitude spikes and high-frequency $(>25 \mathrm{~Hz})$ discharge of the olfactory tubercle neurons. The signal, amplified and displayed in a usual manner, was fed to a differential amplitude discriminator generating square pulses from which integrated firing rate histograms were obtained.

Activation by excitatory substances. Alternate microiontophoretic applications of the excitatory substances (KA and CCK-8S) were carried out adjusting the ejecting current to induce a similar degree of neuronal activation with each of them. Care was taken to keep the activations induced by KA in a physiological range $(10-20 \mathrm{~Hz})$. The automatic current balancing was then briefly removed and the barrel containing the $2 \mathrm{M} \mathrm{NaCl}$ solution was used for microiontophoretic applications of $\mathrm{Na}^{+}$or $\mathrm{Cl}^{-}$in order to detect any artifactual activation by the saline solution.

In the first series of experiments, on the effect of acute haloperidol, the neuronal responsiveness to the excitatory substances used was assessed by determining the degree of activation $(\mathrm{Hz} / \mathrm{nA})$ as the mean of the increase of the firing activity during the application. The effect of acute intravenous administration of haloperidol on the responsiveness to $\mathrm{CCK}-8 \mathrm{~S}$ and $\mathrm{KA}$ was assessed by comparing the degree of activation before and 3-5 $\mathrm{min}$ after the injection of the neuroleptic. In order to respect this time delay, only 1 or 2 cells were recorded after the injection, whereas $6-8$ cells could be recorded before the injection.
In the second series of experiments, on the effect of long-term haloperidol, since the patterns of the excitatory responses were more complex, 3 parameters were measured to assess neuronal responsiveness: (1) the minimal current (nA) required to increase by $100 \%$ the basal firing rate of the neuron; (2) the degree of activation (see above); and (3) the number of spikes generated $/ n A$ obtained by dividing the total number of spikes induced by the microiontophoretic application by the microiontophoretic current applied. All applications were of a $50 \mathrm{sec}$ duration. The count of the spikes generated was arbitrarily stopped $10 \mathrm{~min}$ after the end of the application for neurons whose activation persisted for several min after the end of the application of CCK-8S (see Results). Some neurons responded to a low-current application of CCK-8S, but not of KA, by an almost immediate depolarization inactivation (a widening of the wave form and a decrease of its amplitude, resulting eventually in the disappearance of the firing activity) (Table 1). These latter neurons were not used for the above-mentioned calculations. All other neurons were included in the calculations, neurons not responding to CCK-8S were included with a degree of activation equal to zero.

Suppression by DA. Serial $50 \mathrm{sec}$ applications of DA were carried out at fixed intervals during neuronal activations by CCK $-8 \mathrm{~S}$ or KA. Fixed intensities of current of 5 and $20 \mathrm{nA}$ were used for the microiontophoretic applications of DA. The degree of suppression induced by DA was determined by comparing the firing activity of the neuron for 50 $\mathrm{sec}$, before and during microiontophoretic applications of DA. The effect of acute intravenous administration of haloperidol on the responsiveness to DA was assessed by comparing the degree of suppression by DA before and 3-5 min after the injection of the neuroleptic. The effect of long-term administration of haloperidol was determined by comparing the degree of suppression by DA in control rats and in rats treated for 3 or 5 weeks with this neuroleptic.

Histological verifications. A fast green deposit was left at the last recording site, at the end of the experiment, by passing a $-25 \mu \mathrm{A}$ current for $20 \mathrm{~min}$ through the recording barrel. Frozen histological sections were prepared for histological verification of recording sites.

\section{Quantitative receptor autoradiographic studies}

Tissue preparation. Brain slices were prepared as previously described by Herkenkam and Pert (1982). Briefly, rats acutely or chronically treated ( 5 weeks) with haloperidol were decapitated and their brains rapidly immersed in 2 -methylbutane at $-40^{\circ} \mathrm{C}$, mounted on cryostat chucks, and cut at $-14^{\circ} \mathrm{C}$ into $20-\mu \mathrm{m}$-thick coronal sections, corresponding to A $8920-\mathrm{A} 8620 \mu \mathrm{m}$ in the atlas of Konig and Klippel (1963). Sections were thaw-mounted onto precleaned gelatin-coated slides, air-dried at $4^{\circ} \mathrm{C}$ for about $2 \mathrm{hr}$ and stored at $-14^{\circ} \mathrm{C}$ until use.

Cholecystokinin binding assay. Sections were preincubated for $15 \mathrm{~min}$ at $23-25^{\circ} \mathrm{C}$ in $50 \mathrm{~mm}$ Tris $\cdot \mathrm{HCl}, \mathrm{pH} 7.7$, containing $5 \mathrm{~mm} \mathrm{MgCl}_{2}$ and $0.2 \%$ BSA followed by a 120 min incubation at the same temperature in $50 \mathrm{~mm}$ Tris $\cdot \mathrm{HCl}$, pH 7.7 , containing $5 \mathrm{~mm} \mathrm{MgCl}_{2}, 0.35 \mathrm{~mm}$ bacitracin, $0.2 \% \mathrm{BSA}$, and $1.0 \mathrm{~mm}$ dithiothreitol with $34 \mathrm{pm} \mathrm{N} \alpha\left[^{125}\right.$ I-desa- 


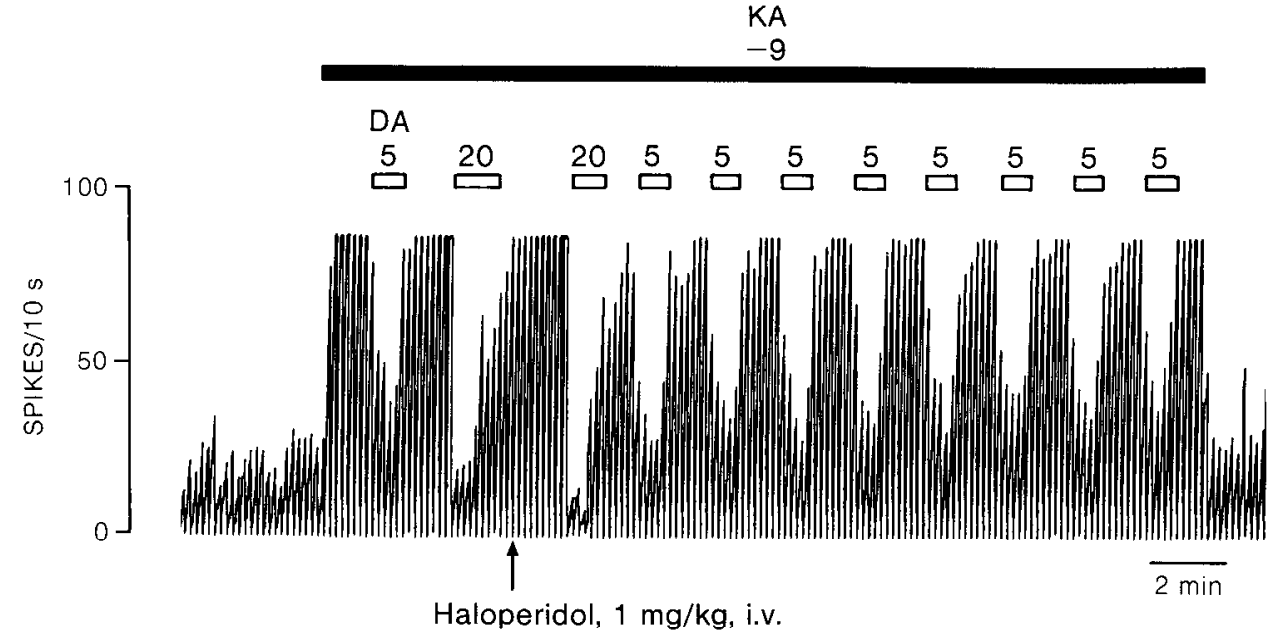

Figure 1. Integrated firing rate histogram of an accumbens neuron showing the unchanged responsiveness to $\mathrm{KA}$ and DA after the intravenous administration of haloperidol $(1 \mathrm{mg} / \mathrm{kg})$. minotyrosyl] CCK 26-33 ( ${ }^{125}[$-CCK $26-33)(2000 \mathrm{Ci} / \mathrm{mmol} ; 1 \mathrm{Ci}=3.7$ $\times 10^{\text {in }}$ becquerels; New England Nuclear, Boston, MA). Adjacent tissue sections were incubated with $1 \mu \mathrm{M}$ CCK $29-33$ to define specific labeling. At the end of the incubation period, the slides were transferred to 4 sequential rinses of $7.5 \mathrm{~min}$ in $4^{\circ} \mathrm{C}$ incubation buffer and subsequently dipped in cold $50 \mathrm{~mm}$ Tris-HCl buffer for $30 \mathrm{sec}$. Under these conditions, the specific binding represented $70-75 \%$ of the total binding, depending upon brain areas. The slides were then rapidly dried under a stream of cold air and tightly juxtaposed to tritium-sensitive films (Ultrofilm, LKB), along with iodine standards (Amersham, Oakville, Ontario) and stored at room temperature for 2 weeks. The films were then processed in Kodak D 19 at $22^{\circ} \mathrm{C}$ for $4 \mathrm{~min}$ and fixed for $5 \mathrm{~min}$.

$D A D 1$ and $D 2$ binding assays. Adjacent sections to those used for CCK binding assay were incubated for $60 \mathrm{~min}$ at room temperature in $50 \mathrm{~mm}$ Tris $\cdot \mathrm{HCl}$, pH 7.4, containing $120 \mathrm{~mm} \mathrm{NaCl}, 5 \mathrm{~mm} \mathrm{KCl}, 2 \mathrm{~mm}$ $\mathrm{CaCl}_{2}$, and $1 \mathrm{~mm} \mathrm{MgCl}$, with $1 \mathrm{nM}^{3} \mathrm{H}-\mathrm{SCH} 23390(87 \mathrm{Ci} / \mathrm{mmol} ; 1 \mathrm{Ci}$ $=3.7 \times 10^{10}$ becquerels; New England Nuclear) to evaluate D1 receptor density. The tissue sections were submitted to 5 rinses of 2 min each in cold incubation buffer and then dipped in cold distilled $\mathrm{H}_{2} \mathrm{O}$. Nonspecific binding was determined in the presence of $1 \mu \mathrm{M} \mathrm{SCH} 23390$ and represented $75-90 \%$ of total binding. D2 receptor density was evaluated by incubating forebrain tissue sections for $60 \mathrm{~min}$ at room temperature, in $50 \mathrm{~mm}$ Tris $\cdot \mathrm{HCl}$, pH 7.4, containing $120 \mathrm{mM} \mathrm{NaCl}, 5 \mathrm{~mm}$ $\mathrm{KCl}, 2 \mathrm{mM} \mathrm{CaCl}_{2}, 1 \mathrm{~mm} \mathrm{MgCl}, 5.7 \mathrm{~mm}$ ascorbic acid with $0.75 \mathrm{nM}^{3} \mathrm{H}-$ spiperone $(25.1 \mathrm{Ci} / \mathrm{mmol}$; New England Nuclear). At the end of incubation periods, the tissue sections were washed for 5 periods of 2 min in cold incubation buffer and subsequently dipped in cold distilled water. Under these conditions nonspecific binding, determined in presence of $1 \mu \mathrm{M}(+)$ butaclamol represented $65-80 \%$ of the total binding. The slides were processed as described above for CCK binding assay and exposed to tritium-sensitive films for 1 month along with tritium standards (Amersham).

Quantitative autoradiography. The films were quantitated using a computerized image analyzer (Spatial Data System, Melbourne, FL) and tritium standard (Amersham). Specific binding in each brain area considered was determined by subtracting densities obtained for nonspecific images from those obtained for total images.

Statistical analysis. The distributions of responsive and unresponsive neurons to CCK-8S and of those inactivated by the peptide in control and long-term haloperidol-treated rats were compared using the $\chi^{2}$ test. The effects of CCK-8S, KA, and DA were compared before and after the acute administration of haloperidol using the 2-tailed Student's $t$ test. The same statistical analysis was used to compare the effects of these substances in control rats to their effects in long-term haloperidoltreated rats, as well as to compare binding densities in these 2 groups.

\section{Results}

\section{Electrophysiological studies}

In a first series of experiments, the effects of microiontophoretic applications of CCK-8S $(10 \mu \mathrm{M}), \mathrm{KA}$, and DA were assessed before and after intravenous administration of haloperidol (1 $\mathrm{mg} / \mathrm{kg}, \mathrm{i}$.v.). Six to eight neurons were tested before the injection, but only 1 or 2 neurons were recorded after since a standard 5 min postinjection period was adopted for determining the effect of the drug. Seventy accumbens neurons were tested before the acute administration of haloperidol. As previously observed (Debonnel and de Montigny, 1988), microiontophoretic applications of KA excited all neurons recorded (Fig. 1). Sixty out of those 70 accumbens neurons also responded to CCK-8S by an increase of their firing activity. During activations by CCK$8 \mathrm{~S}$, but not by KA, some neurons showed signs of depolarization, i.e., a widening of the wave form and a decrease of its amplitude, even when relatively low firing rates were attaincd $(6-8 \mathrm{~Hz})$. Other neurons responded by an almost immediate depolarization inactivation upon CCK-8S application (Table 1), resulting in the disappearance of the firing activity. Applications of 5 or $20 \mathrm{nA}$ of DA produced a dose-dependent suppression

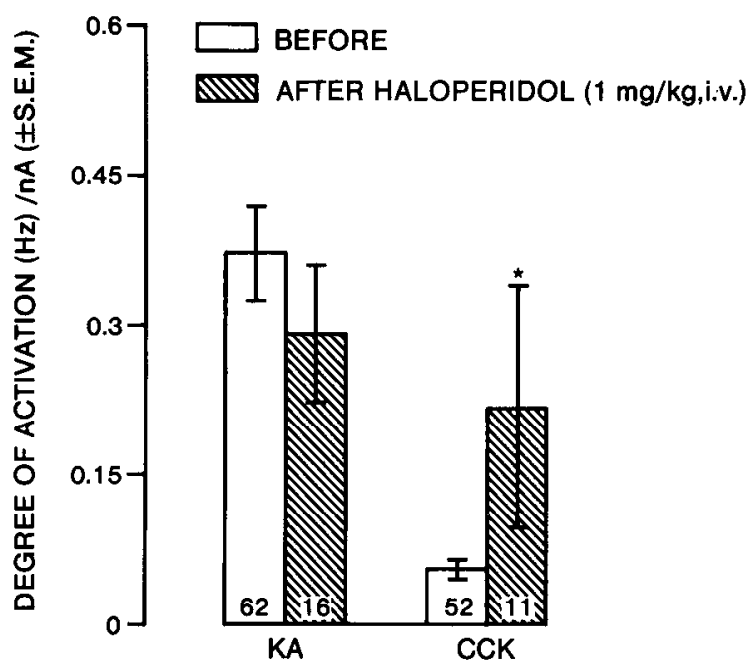

Figure 2. Degree of activation of accumbens neurons by CCK and KA before and after the acute administration of haloperidol, measured as the mean of the increase of the firing activity generated $/ \mathrm{nA}$ of microiontophoretic application. The number of neurons tested is given at the bottom of each column. ${ }^{*} p<0.01$ (2-tailed Student's $t$ test). 

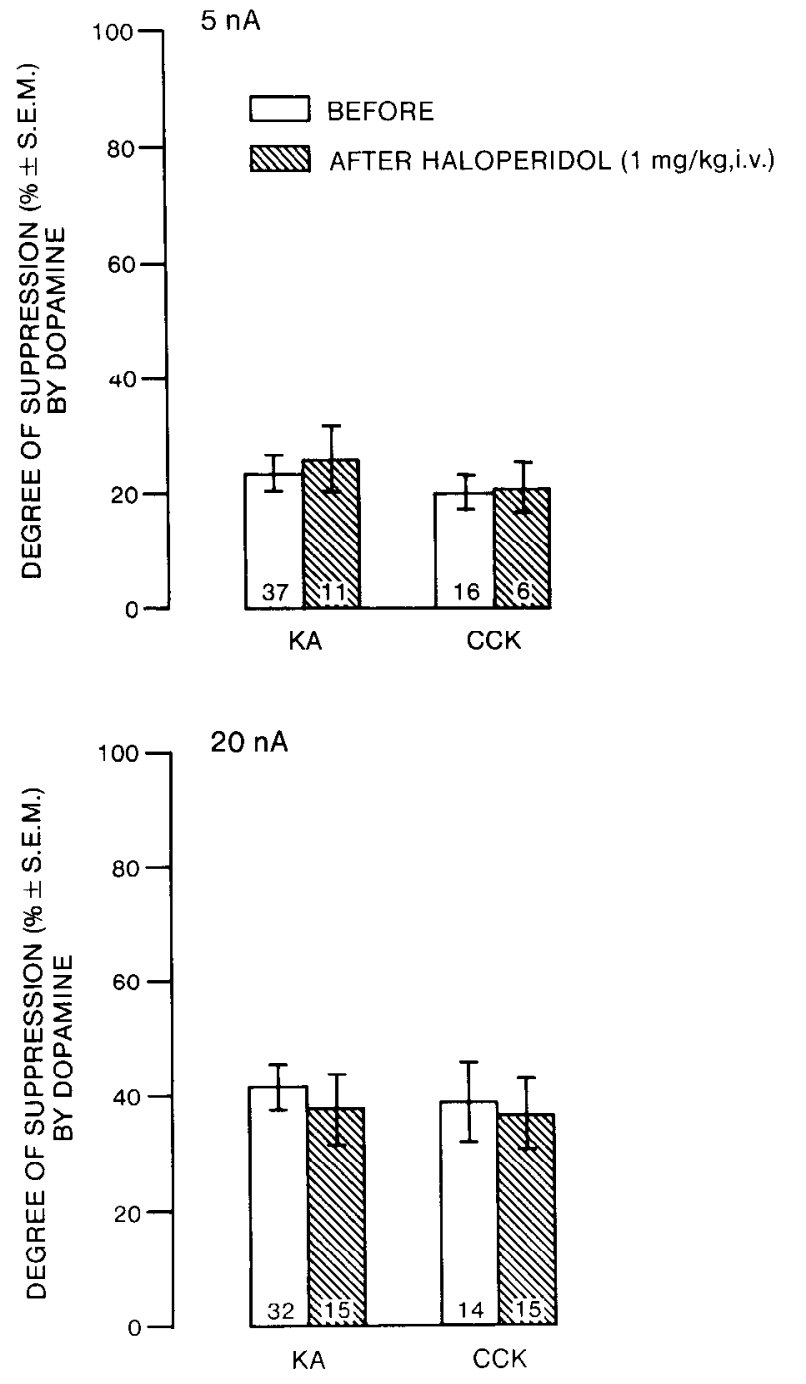

Figure 3. Degree of suppression of CCK- and KA-induced activations of accumbens neurons by microiontophoretic applications of 5 and 20 $\mathrm{nA}$ of DA before and after the acute administration of haloperidol. The degree of suppression was measured by comparing the number of spikes generated by each substance before and during a $50 \mathrm{sec}$ application of DA.

of the KA- and CCK-induced firing activities (Fig. 1). The degree of suppression induced by both currents of DA was not significantly different whether applied during CCK-8S- or KA-induced activations. When applied on a neuron in a CCK-8Sinduced state of depolarization inactivation, DA induced a reappearance of the firing activity.

Twenty-four accumbens neurons were tested after the injection of haloperidol ( $1 \mathrm{mg} / \mathrm{kg}, \mathrm{i} . \mathrm{v}$.$) . Haloperidol increased the$ basal firing activity of these neurons from $0.76 \pm 0.05$ to 1.1 $\pm 0.07 \mathrm{~Hz}(p<0.05)$, without modifying significantly their responsiveness to $\mathrm{KA}$ (Fig. 2). However, it increased their firing activity during CCK-8S applications, resulting in a significant increase of the degree of activation (Fig. 2). This dose of haloperidol did not alter the suppressant effect of microiontophoretic applications of DA with 5 and $20 \mathrm{nA}$, on KA- or CCK-8Sinduced activations (Figs. 1,3). Subsequent intravenous administrations of haloperidol up to a cumulative dose of $5 \mathrm{mg} / \mathrm{kg}$ also failed to modify the effect of DA (data not shown).
Table 2. Effect of long-term treatment with haloperidol on the basal firing activity $(\mathrm{Hz} \pm \mathrm{SEM})$ of accumbens neurons

\begin{tabular}{llll} 
& & \multicolumn{3}{l}{ Haloperidol $^{a}$} \\
\cline { 3 - 4 } CCK & Controls & weeks & 5 weeks \\
\hline $1 \mu \mathrm{M}^{b}$ & $0.6 \pm 0.1$ & $1.0 \pm 0.1$ & $1.6 \pm 0.2^{d}$ \\
& $(22)^{c}$ & $(17)$ & $(33)$ \\
$10 \mu \mathrm{M}^{b}$ & $0.7 \pm 0.1$ & $1.0 \pm 0.2$ & $2.2 \pm 0.4^{d, e}$ \\
& $(56)$ & $(18)$ & $(20)$
\end{tabular}

${ }^{a}$ Experiments were carried out after 3 or 5 weeks of treatment with long-acting haloperidol decanoate $(4 \mathrm{mg} / \mathrm{kg}$, i.m., once a week).

${ }^{n}$ The concentrations of CCK-8S correspond to those of the solution present in one side barrel of the micropipette. A retention current of $10 \mathrm{nA}$ was applied to that barrel while determining the basal firing activity.

The number in brackets indicates the number of neurons recorded.

${ }^{2} p<0.001$ compared with corresponding control value (2-tailed Student's $t$ test). ${ }^{\text {e }} p<0.05$ compared with CCK $1 \mu \mathrm{M}$ value in the same group (2-tailed Student's $t$ test).

In a second series of experiments, rats were injected once weekly intramuscularly with $4 \mathrm{mg} / \mathrm{kg}$ of the long-acting haloperidol decanoate for 3 or 5 weeks. As illustrated in Figure 4, $A, C$, the responsiveness of accumbens neurons to microiontophoretic applications of KA remained unchanged after both the 3 and 5 week treatments. None of the parameters measured to determine the efficacy of KA (minimal effective current, degree of activation, and number of spikes generated $/ \mathrm{nA}$ ) were significantly affected (Figs. 5, 6).

However, after long-term haloperidol treatment, there was a marked increase in the neuronal response to CCK-8S. The number of neurons responsive to both concentrations of CCK-8S was significantly increased, as well as the number of neurons responding to microiontophoretic applications of $10 \mu \mathrm{M} \mathrm{CCK}$ $8 \mathrm{~S}$ by a depolarization inactivation (Table 1). This increased responsiveness to $\mathrm{CCK}-8 \mathrm{~S}$ was also evidenced by an increase in the basal firing activity of the neurons after 5 weeks of haloperidol treatment, presumably due to a leak of CCK-8S despite the high retention current used, as suggested by the fact that this increase was more pronounced with the $10 \mu \mathrm{M}$ than the 1 $\mu \mathrm{M}$ solution of CCK-8S (Table 2). As illustrated in Figure 4, $A$, $B$, the minimal current required to activate the neurons was much lower and the activation (which stopped immediately after the end of the application in control rats) persisted long after the application of CCK-8S was terminated in long-term haloperidol rats. In some of the neurons, the $50 \mathrm{sec}$ application of CCK-8S resulted in an activation lasting for as long as 10-15 $\min$ (Fig. $4 B$ ).

The parameters measured to assess neuronal responsiveness to $\mathrm{CCK}-8 \mathrm{~S}$ were differentially affected, depending upon the concentration of the solution used and the duration of the neuroleptic treatment. The minimal effective current was significantly lower only after 5 weeks of treatment when the $1 \mu \mathrm{M}$ solution of CCK-8S was used, whereas with the $10 \mu \mathrm{M}$ solution, the minimal effective current was lower in both the 3 and 5 week treatment groups (data not shown).

With the $1 \mu \mathrm{M}$ solution of CCK-8S, the degree of activation was increased 2-fold after 3 weeks of treatment, whereas it was increased by more than 50 -fold after 5 weeks of treatment. With the $10 \mu \mathrm{M}$ solution, the degree of activation was increased by 10 -fold after 3 weeks, and by 25 -fold after 5 weeks of treatment (Fig. 5). 
A
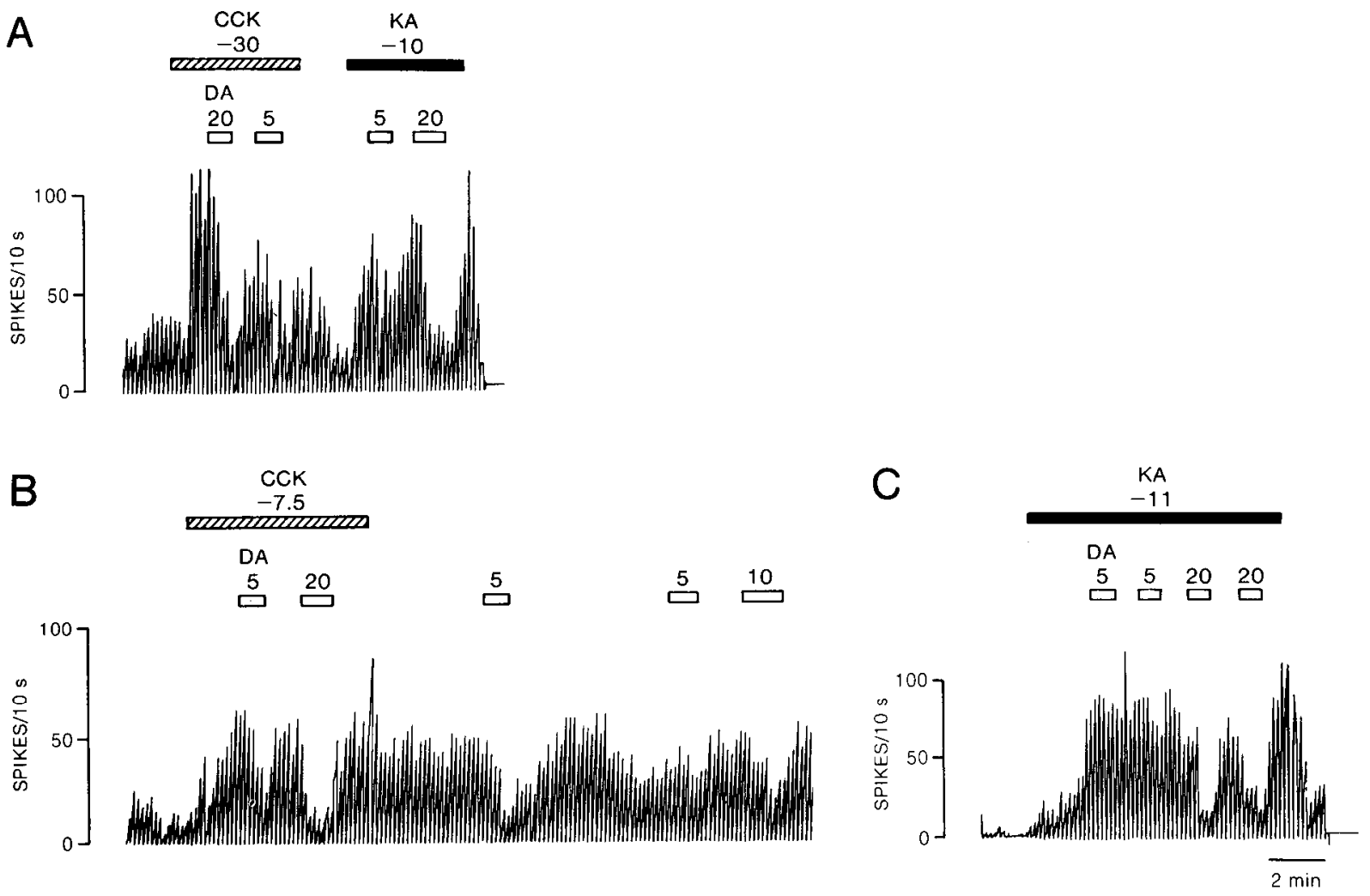

Figure 4. Integrated firing rate histograms of accumbens neurons showing their response to DA during their activation with either CCK-8S or $\mathrm{KA}$ in a control rat $(A)$ and in long-term haloperidol-treated rats $(B, C)$. Time base applies to all traces.

With the $1 \mu \mathrm{M}$ solution of CCK-8S, the total number of spikes generated/nA was increased 3 -fold after 3 weeks and 100 -fold after 5 weeks of treatment. With the $10 \mu \mathrm{M}$ solution, it was increased by 50 -fold in rats treated for 3 weeks and by more than 200 -fold after 5 weeks of treatment with haloperidol (Fig. 6).

The degree of suppression of KA-induced activation by microiontophoretically applied DA was unchanged following either the 3 or 5 week haloperidol treatment (Fig. 7). There was a slight, although statistically significant, increase in the effect of DA when applied with a $5 \mathrm{nA}$ current, but not when applied with a $20 \mathrm{nA}$ current, during CCK-8S-induced activation (Fig. 7).

\section{Receptor studies}

An acute administration of haloperidol did not produce significant changes in CCK, $D_{1}$ and $D_{2}$ binding parameters as assessed by quantitative receptor autoradiography (data not shown). However, after a 5 week treatment, the amounts of specific ${ }^{125}$ I-CCK 26-33 binding were significantly increased in the nucleus accumbens and in the olfactory tubercle but not in the caudate putamen (Table 3). These increases in CCK binding are unlikely to be related to the presence of haloperidol in the tissues, since this butyrophenone did not have a direct effect on CCK binding at concentrations up to $10 \mu \mathrm{M}$ (Gaudreau et al., 1983). Moreover, increases were observed only in certain brain regions, making it unlikely to be related to the presence of haloperidol in the tissue sections.

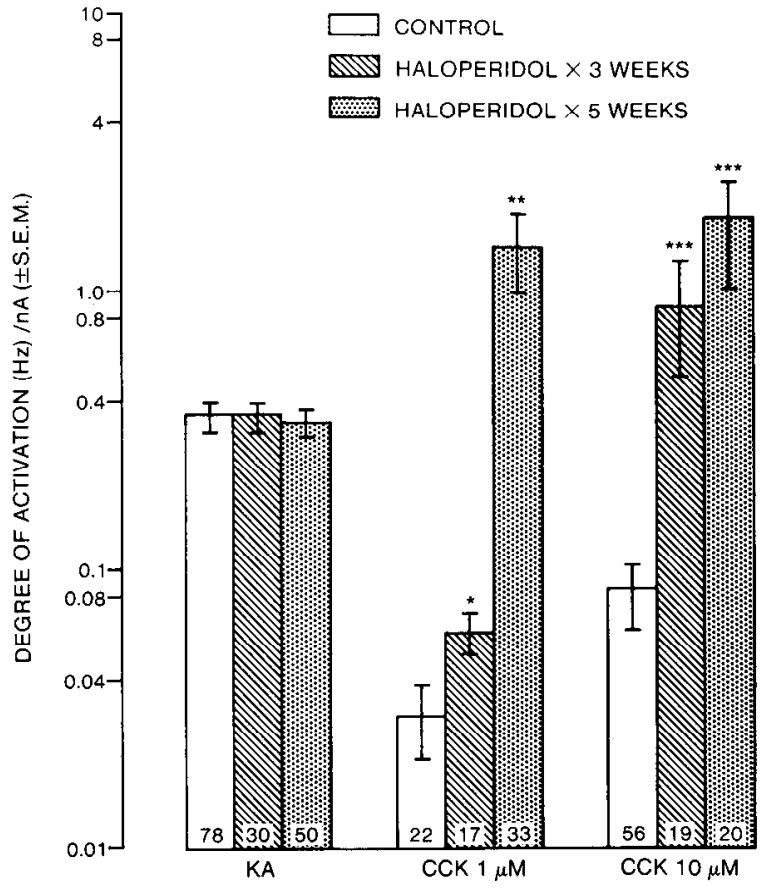

Figure 5. Degree of activation of accumbens neurons by CCK and KA in control rats and in rats chronically treated with haloperidol for 3 or 5 weeks, measured as the mean increase of the firing activity generated/ $\mathrm{nA}$ of microiontophoretic application. ${ }^{*} p<0.05,{ }^{* *} p<0.001,{ }^{* * *} p<$ 0.0001 (2-tailed Student's $t$ test). 


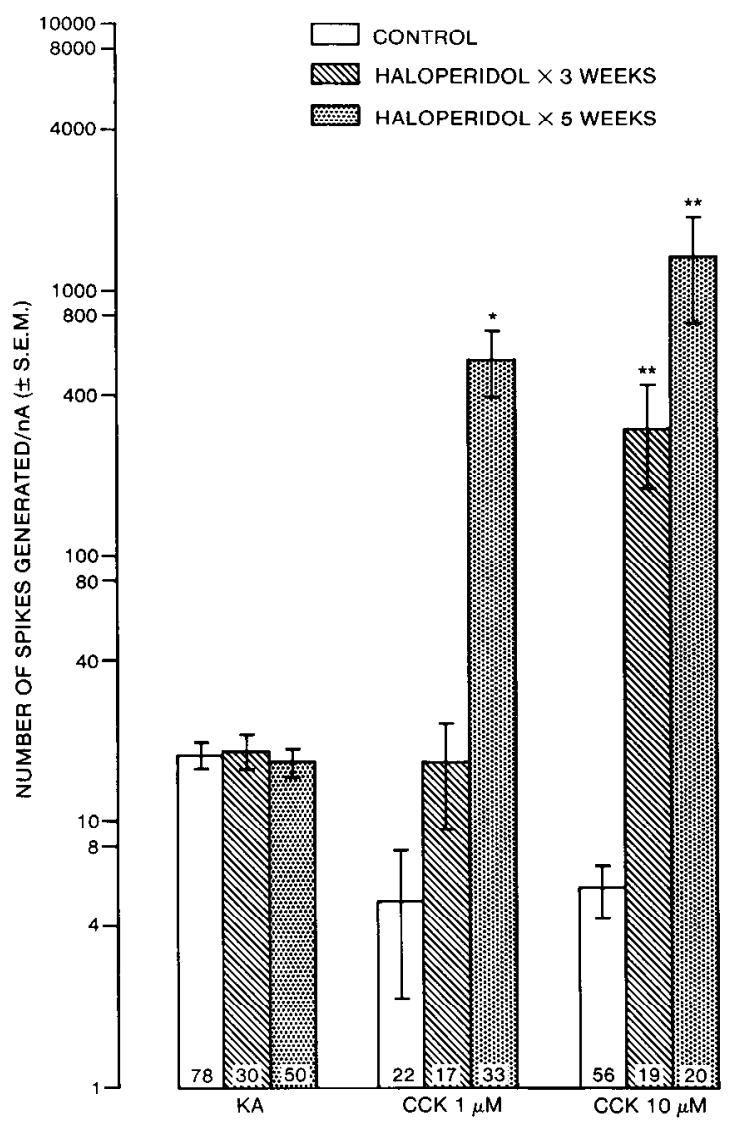

Figure 6. Number of spikes generated/nA of CCK-8S and KA by accumbens neurons in control rats and in rats treated for 3 or 5 weeks with haloperidol. All microiontophoretic applications were of a $50 \mathrm{sec}$ duration. ${ }^{*} p<0.01,{ }^{* *} p<0.001$ (2-tailed Student's $t$ test).

As expected, $\mathrm{D}_{2} /{ }^{3} \mathrm{H}$-spiperone, but not $\mathrm{D}_{1} /{ }^{/ 3} \mathrm{H}-\mathrm{SCH} 23390$, binding increased in the nucleus accumbens and in the caudate putamen following the chronic treatment (Table 4).

\section{Discussion}

The responsiveness of accumbens neurons to the microiontophoretic application of KA after both acute and long-term treatment with haloperidol was not significantly changed, in contrast to the increased responsiveness of accumbens neurons to this amino acid, following a 6-hydroxydopamine lesion of the VTA (Debonnel and de Montigny, 1988). The latter observation might be ascribed to a decreased release of glutamate in the accumbens, resulting from a reduced tonic activation of $\mathrm{D} 2$ dopaminergic receptors on the terminals of the glutamatergic hippocampalaccumbens pathway (Yang and Mogenson, 1986). The present results suggest that, contrary to a VTA lesion which completely abolishes DA release, blockade of D2 receptors by long-term treatment with haloperidol may not affect the release of glutamate to a similar extent.

Most accumbens neurons showed a clear excitatory response to CCK-8S, as observed by several investigators (DeFrance et al., 1984; White and Wang, 1984; Wang and Hu, 1986; Debonnel and de Montigny, 1988). The neuronal responsiveness to CCK-8S was increased after both acute and long-term treatment with haloperidol. However, the magnitude of this increase was much greater in long-term treated rats than following the acute administration of haloperidol.
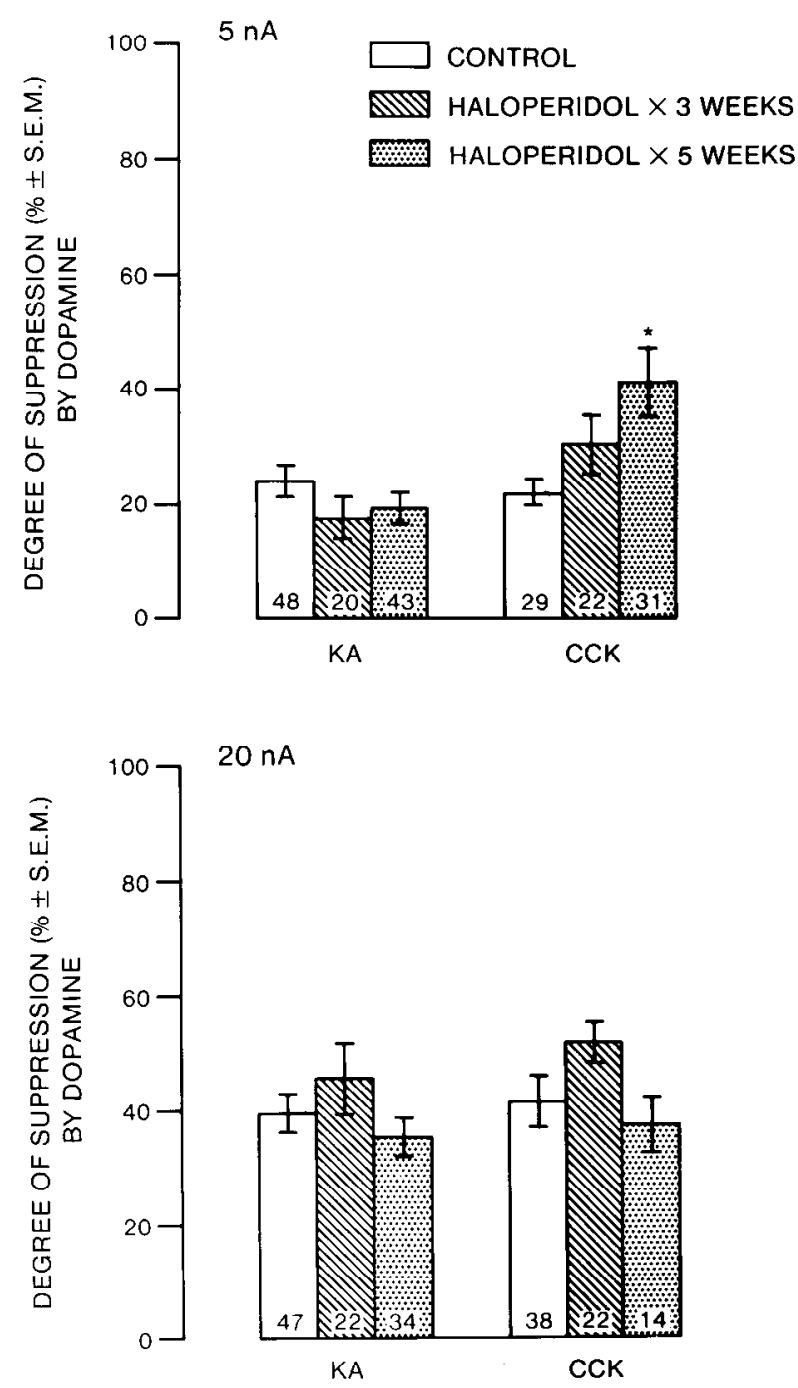

Figure 7. Degree of suppression of CCK-8S- and KA-induced activations of accumbens neurons by microiontophoretic applications of DA with 5 and $20 \mathrm{nA}$, in control rats and rats treated with haloperidol for 3 or 5 weeks. The degree of suppression was measured by comparing the number of spikes generated by KA or CCK before and during a 50 sec application of DA. ${ }^{*} p<0.05$ (2-tailed Student's $t$ test).

The acute administration of $1 \mathrm{mg} / \mathrm{kg}$ of haloperidol induced a 4-fold increase in the responsiveness of accumbens neurons to the microiontophoretic applications of CCK-8S (Fig. 2). We have no definite interpretation for this effect of haloperidol. It is known that the acute administration of haloperidol induces an almost immediate increase of the release of endogenous DA (Scatton et al., 1975, 1976; Louilot et al., 1985; Kuhr et al., 1986; Boyar and Altar, 1987), most likely due to an increase in the firing activity of DA neurons and to an increase in the number of active A10 dopaminergic cells (Bunney et al., 1973; Bunney and Grace, 1978; Grace and Bunney, 1980), as well as to the blockade of dopaminergic autoreceptors (Nowycky and Roth, 1978; Nowak et al., 1983; Parker and Cubeddu, 1985). Moreover, it has been shown that the acute administration of DA antagonists also increases the release of endogenous CCK (Fukamauchi et al., 1987a). Assuming that endogenous DA activates primarily D2 receptors (see below), given the potent D2 antagonistic effect of haloperidol, it can be postulated that, despite the increased release of DA, the acute administration of 
Table 3. Comparative ${ }^{125}$ I-CCK $26-33$ binding in control rats and long-term haloperidol-treated rats

\begin{tabular}{lll} 
& \multicolumn{2}{l}{$\begin{array}{l}\text { Binding } \\
\text { (pmol/gm tissue, wet weight) }\end{array}$} \\
\cline { 2 - 3 } Tissue & Controls & Haloperidol $^{b}$ \\
\hline Nucleus accumbens & $3.65 \pm 0.36$ & $7.00 \pm 0.47^{e}$ \\
Olfactory tubercle & $(12)^{c}$ & $(12)$ \\
& $3.71 \pm 0.31$ & $5.86 \pm 0.54^{d}$ \\
Caudate putamen & $(12)$ & $(8)$ \\
& $1.28 \pm 0.17$ & $1.09 \pm 0.42$ \\
& $(10)$ & $(8)$
\end{tabular}

${ }^{a}$ Binding data were derived from quantitative receptor radioautography.

${ }^{h}$ Long-lacting haloperidol decanoate was administered for 5 weeks at a dose of 4 $\mathrm{mg} / \mathrm{kg}$, i.m., once a week.

c The numbers in parentheses represent the number of individual data obtained from 4 control and 4 treated animals.

${ }^{d} p<0.01$.

${ }^{e} p<0.001$ compared with corresponding control values (2-tailed Student's $t$ test)

this agent results in a decreased activation of $\mathrm{D} 2$ receptors by endogenous DA. Hence, it is possible that these 2 modifications of the tonic input to postsynaptic neurons might underlie the increased effect of microiontophoretic application of CCK-8S following acute haloperidol administration.

The treatment with long-acting haloperidol for 5 weeks increased ${ }^{125}$ I-CCK binding (Table 3 ), which could reflect an increment in the number of CCK receptors (Chang et al., 1983; Mishra, 1983). These results could appear contradictory to several studies reporting an increase or no change in CCK content of the accumbens following long-term neuroleptics (Govoni et al., 1982; Frey, 1983; Gysling and Beinfeld, 1984). However, a decrease in the release of CCK after long-term neuroleptic treatments could increase $\mathrm{CCK}$ content in the nerve terminal but still induce an increase in CCK binding at the postsynaptic level. The increased responsiveness to CCK-8S after long-term haloperidol treatment is consistent with an increase in the capacity of CCK receptors in these conditions. A similar increase in the responsiveness to $\mathrm{CCK}$ and in the number of $\mathrm{CCK}$ binding sites has been reported after lesioning of the presynaptic neurons in electrophysiological and radioligand binding studies (Chang et al., 1983; Hu and Wang, 1985; Debonnel and de Montigny,
1988), consistent with decreased levels of CCK after such a lesion (Marley et al., 1982).

In the present study, the apparent time course and the magnitude of the increase in the responsiveness to CCK-8S following long-term haloperidol were different depending on the concentration used and the parameter measured. With the $1 \mu \mathrm{M}$ solution of CCK-8S, the minimal effective current was significantly lower, but only after 5 weeks of treatment with haloperidol. However, with the same solution, the number of spikes generated $/ \mathrm{nA}$ was increased by $50 \%$ after 3 weeks of treatment (Fig. 6). This increase was relatively small compared with that obtained with the $10 \mu \mathrm{M}$ solution of CCK-8S. With the $10 \mu \mathrm{M}$ solution of CCK-8S, the minimal effective current was $60 \%$ lower after 3 weeks of treatment. At that time, the number of spikes generated/nA was increased by 50 -fold; it was increased by 200 -fold after 5 weeks of treatment (Fig. 6). This increase was mainly due to the prolonged duration of the activation induced by the microiontophoretic application of CCK-8S. Since it has been reported that, after a 3 week neuroleptic treatment, CCK binding parameters were unchanged in the nucleus accumbens (Gaudreau et al., 1986; Fukamauchi et al., 1987b), the present electrophysiological finding that the 3 week haloperidol treatment increased only marginally the responsiveness to CCK$8 \mathrm{~S}$ relative to the 5 week treatment (Figs. 5, 6) might suggest that a 3 week treatment could be too short to bring about a detectable increase in the number of CCK binding sites.

Microiontophoretic applications of DA suppressed the firing activity of accumbens neurons when activated either with KA or CCK-8S, in keeping with previous studies in this nucleus (Akaike et al., 1983, 1984; Debonnel and de Montigny, 1988). The fact that DA exerted a similar degree of suppression on KA- and CCK-8S-induced activations in control rats, as well as after acute or long-term treatment with haloperidol (Figs. 3, 7), suggests a nonspecific postsynaptic interaction between $\mathrm{CCK}$ and DA. This lack of potentiation of the effect of DA by CCK8S has already been reported (Wang and $\mathrm{Hu}, 1986$; Debonnel and de Montigny, 1988) but is in apparent discrepancy with reports of a postsynaptic potentiation of DA by CCK-8S (DeFrance et al., 1984; Crawley et al., 1985a, b). It has been suggested that the apparent potentiation of DA by CCK might be indirect, involving other neurotransmitters (Wang and $\mathrm{Hu}$, 1986). That there might not be a truly specific interaction be-

Table 4. Comparative $D_{1}$ and $D_{2}$ receptor binding in control rats and long-term haloperidol-treated rats

\begin{tabular}{|c|c|c|c|c|}
\hline \multirow[b]{3}{*}{ Tissue } & \multicolumn{4}{|c|}{ Binding (pmol/gm tissuc, wet wcight) ${ }^{r}$} \\
\hline & \multicolumn{2}{|c|}{$\mathrm{D}_{1} /{ }^{3} \mathrm{H}-\mathrm{SCH} 23390$} & \multicolumn{2}{|c|}{$\mathrm{D}_{2} /{ }^{3} \mathrm{H}$-spiperone } \\
\hline & Controls & Haloperidol $^{b}$ & Controls & Haloperidols \\
\hline Nucleus accumbens & $\begin{array}{l}150 \pm 10 \\
(6)^{c}\end{array}$ & $\begin{array}{l}140 \pm 10 \\
(6)\end{array}$ & $\begin{array}{l}170 \pm 10 \\
(8)\end{array}$ & $\begin{array}{l}340 \pm 30^{d} \\
(6)\end{array}$ \\
\hline Olfactory tubercle & $\begin{array}{l}290 \pm 20 \\
(6)\end{array}$ & $\begin{array}{l}310 \pm 20 \\
(6)\end{array}$ & $\begin{array}{l}420 \pm 40 \\
(8)\end{array}$ & $\begin{array}{l}510 \pm 46 \\
(8)\end{array}$ \\
\hline Caudate putamen & $\begin{array}{l}290 \pm 20 \\
(6)\end{array}$ & $\begin{array}{l}300 \pm 33 \\
(6)\end{array}$ & $\begin{array}{l}180 \pm 10 \\
(7)\end{array}$ & $\begin{array}{l}260 \pm 12^{d} \\
(6)\end{array}$ \\
\hline
\end{tabular}

\footnotetext{
${ }^{a}$ Long-acting haloperidol decanoate was administered for 5 weeks at a dose of $4 \mathrm{mg} / \mathrm{kg}$, i.m., once a week.

"Binding data were derived from quantitative receptor radioautography.

c The numbers in parentheses represent the number of individual data obtained from 4 control and 4 treated animals.

${ }^{d} p<0.01$ compared with corresponding control values (2-tailed Student's $t$ test).
} 
tween CCK and DA on postsynaptic neurons is further suggested by the reported potentiation of $\mathrm{ACh}$ by CCK (DeFrance et al., 1984).

Neither acute administration nor 3 week treatment with haloperidol modified the responsiveness of accumbens neurons to DA. After 5 weeks of treatment, the degree of suppression induced by applications of $5 \mathrm{nA}$ of DA on CCK-8S-activated neurons was slightly incrcascd (Fig. 7). However, the biological significance of this result is questionable inasmuch as the response to the $20 \mathrm{nA}$ application of DA was not altered (Fig. 7). The fact that acute and long-term haloperidol treatments did not significantly change the responsiveness of accumbens neurons to DA could appear most intriguing, given the well-documented supersensitivity of dopaminergic receptors after longterm neuroleptic treatments (Burt et al., 1977; Muller and Seeman, 1978; Skirboll and Bunney, 1979; Severson et al., 1984). However, several studies have reported that, contrary to microiontophoretic applications of haloperidol which antagonize DA-induced inhibition of caudate or accumbens neurons (Akaike et al., 1983, 1984), systemic administration of neuroleptics is ineffective in blocking the effects of microiontophoretic applications of DA (Ben-Ari and Kelly, 1976; Somjen et al., 1976; Zarzecki et al., 1977; Skirboll and Bunney, 1979; Johnson et al., 1986). This has been attributed to the fact that DA applied microiontophoretically would exert its effect primarily through D1 receptor activation, whereas haloperidol administered systemically would block preferentially D2 receptors. Hence, only microiontophoretic applications of haloperidol would produce a local concentration sufficient to block both types of receptors (Johnson et al., 1986). This interpretation is supported by the observation of Akaike et al. (1983) that, in the nucleus accumbens, the effect of the microiontophoretic application of DA was blocked by concomitant application of haloperidol but not by that of sulpiride, a selective D2 antagonist. The results of the present binding studies demonstrating an increase of D2 and no change in D1 receptor binding would then explain the unchanged responsiveness to exogenous DA after long-term haloperidol treatment. It is, however, also possible that the electrophysiological effect of microiontophoretically applied DA might be mediated by a type of receptor other than the D1 or D2 subtypes, as already suggested by Akaike et al. (1984).

Long-term haloperidol treatment results in a marked reduction of the firing activity of $\mathrm{A} 9$ and A10 dopaminergic neurons (Bunney and Grace, 1978; Chiodo and Bunney, 1983; White and Wang, 1983; Grace and Bunney, 1986). Roth (1984) has shown that, following a long-term treatment with haloperidol, there is still a releasc of DA, despitc the reduced firing activity of DA neurons. It has been shown that the release of cotransmitters can be differentially affected by changes in the firing rate of the neurons of origin (Lundberg et al., 1986). Hence, as speculative as it might be, a plausible explanation for the results obtained is that at the reduced firing rate of DA neurons in rats treated with long-term haloperidol, DA would still be released in a sufficient amount to maintain a normal sensilivity of its postsynaptic receptors, whereas the release of CCK could be reduced to a greater extent, resulting in a supersensitivity of the postsynaptic neuron.

In clinical studies, divergent results have been reported regarding the effectiveness of CCK-8S in the treatment of schizophrenic patients (for reviews, see Nair and Bloom, 1986; Debonnel et al., 1987). The results of the present studies might explain the apparently discordant results of these clinical trials with CCK-8S in schizophrenia. It is striking that most of the positive results published so far were obtained in patients on long-term neuroleptic treatment. Thus, given the very small doses of CCK-8S administered to these patients (all the more as it is likely that only a small fraction of the peptide administered crosses the blood-brain barrier), one might speculate that a therapeutic effect can be obtained only in patients whose postsynaptic neurons have been rendered supersensitive to $\mathrm{CCK}$ by the prior long-term neuroleptic treatment.

\section{References}

Akaike, A., M. Sasa, and S. Takaori (1983) Effects of haloperidol and sulpiride on dopamine-induced inhibition of nucleus accumbens neurons. Life Sci. 32: 2649-2653.

Akaike, A., M. Sasa, and S. Takaori (1984) Microiontophoretic studies of the dopaminergic inhibition from the ventral tegmental area to the nucleus accumbens neurons. J. Pharmacol. Exp. Ther. 229! 859-864.

Barden, N., Y. Merand, D. Rouleau, S. Moore, G. J. Dockray, and A. Dupont (1981) Regional distributions of somatostatin and cholecystokinin-like immunoreactivities in rat and bovine brain. Peptides 2: 299-302.

Beinfeld, M. C., D. K. Meyer, R. L. Eskay, R. T. Jensen, and H. J. Brownstein (1981) The distribution of cholecystokinin immunoreactivity in the central nervous system of the rat as determined by radioimmunoassay. Brain Res. 212: 51-57.

Ben-Ari, Y., and J. S. Kelly (1976) Dopamine evoked inhibition of single cells of the feline putamen and basolateral amygdala. J. Physiol. (Lond.) 256: 1-22.

Boyar, W. C., and C. A. Altar (1987) Modulation of in-vivo dopamine release by $D_{2}$ but not $D_{1}$ receptor agonists and antagonists. J. Neurochem. 48: 824-831.

Bunney, B. S., and A. A. Grace (1978) Acute and chronic haloperidol treatment: Comparison of effects on nigral dopaminergic cell activity. Life Sci. 23: 1715-1728.

Bunney, B. S., J. R. Walters, R. H. Roth, and G. K. Aghajanian (1973) Dopaminergic neurons: Effects of antipsychotic drugs and amphetamine on single cell activity. J. Pharmacol. Exp. Ther. 185: 560-571.

Bunney, B. S., A. A. Grace, D. W. Hommer, and L. R. Skirboll (1982) Effect of cholecystokinin on the activity of midbrain dopaminergic neurons. In Regulatory Peptide: From Molecular Biology to Function, E. Costa and M. Trabuchi, eds., pp. 429-436, Raven, New York.

Burt, D. R., I. Creese, and S. H. Snyder (1977) Antischizophrenic drugs: Chronic treatment elevates dopamine receptor binding in brain. Science 196: 326-328.

Chang, R. S. L., V. J. Lotti, G. E. Martin, and T. B. Chen (1983) Increase in brain ${ }^{225}$ I-cholecystokinin (CCK) receptor binding following chronic haloperidol treatment, intracisternal 6-hydroxydopamine or ventral tegmental lesions. Life Sci. 32: 871-878.

Chiodo, L. A., and B. S. Bunney (1983) Typical and atypical neuroleptics: Differential effects of chronic administration on the activity of A9 and A10 midbrain dopaminergic neurons. J. Neurosci. 3: $1607-$ 1619.

Chiodo, L. A., A. S. Freeman, and B. S. Bunney (1987) Electrophysiological studies on the specificity of the cholecystokinin receptor antagonist proglumide. Brain Kes. 410: 205-211.

Clark, C. R., P. Daum, and J. Hughes (1986) A study of the cerebral cortex cholecystokinin receptor using two radiolabelled probes: Evidence for a common CCK 8 and CCK 4 cholecystokinin receptor binding site. J. Neurochem. 46: 1094-1101.

Crawley, J. N., D. W. Hommer, and L. R. Skirboll (1984) Behavioral and neurophysiological evidence for a facilitatory interaction between co-existing transmitters cholecystokinin and dopamine. Neurochem. Int. 6: $755-760$

Crawley, J. N., D. W. Hommer, and L. R. Skirboll (1985a) Topographical analysis of nucleus accumbens sites at which cholecystokinin potentiates dopamine-induced hyperlocomotion in the rat. Brain Res. 335: 337-341.

Crawley, J. N., J. A. Stivers, L. K. Blumstein, and S. M. Paul (1985b) Cholecystokinin potentiates dopamine-mediated behaviors: Evidence for modulation specific to a site of coexistence. J. Neurosci. 5: 1972-1983.

Crawley, J. N., J. A. Stivers, D. W. Hommer, L. R. Skirboll, and S. M. Paul (1986) Antagonists of central and peripheral behavioral actions 
of cholecystokinin octapeptide. J. Pharmacol. Exp. Ther. 236: 320330.

Debonnel, G., and C. de Montigny (1988) Increased neuronal responsiveness to cholecystokinin and dopamine induced by lesioning mesolimbic dopaminergic neurons: An electrophysiological study in the rat. Synapse 2: 537-545.

Debonnel, G., M. Poupart, and M. Koenig (1987) Eléments prédictifs d'une réponse positive à la cholécystokinine chez des schizophrènes. J. Psychiatr. Biol. Ther. 25: 7-14.

DeFrance, J. F., R. W. Sikes, and R. B. Chronister (1984) Effects of CCK-8 in the nucleus accumbens. Peptides 5: 1-6.

Dietl, M. M., A. Probst, and J. M. Palacios (1987) On the distribution of cholecystokinin receptor binding sites in the human brain: An autoradiography study. Synapse 1: 169-183.

Dockray, G. J. (1976) Immunochemical evidence of cholecystokininlike peptide in brain. Nature 264: 568-570.

Dodd, J., and J. S. Kelly (1981) The actions of cholecystokinin and related peptide on pyramidal neurons of the mammalian hippocampus. Brain Res. 205: 337-350.

Fredens, K., K. Stengaard-Pedersen, and L. I. Larsson (1984) Localization of enkephalin and cholecystokinin immunoreactivities in the perforant path terminal fields of the rat hippocampal formation. Brain Res. 304: 255-263.

Freeman, A. S., and B. S. Bunney (1987) Activity of A9 and A10 dopaminergic neurons in unrestrained rats: Further characterization and effects of apomorphine and cholecystokinin. Brain Res. 405: 4655 .

Frey, P. (1983) Cholecystokinin octapeptide levels in the rat brain are changed after subchronic neuroleptic treatment. Eur. J. Pharmacol 95: 87-92.

Fukamauchi, F., T. Yoshikawa, S. Kaneno, H. Shibuya, and R. Takahashi (1987a) Dopaminergic agents affected neuronal transmission of cholecystokinin in the rat brain. Neuropeptides 10:207-220.

Fukamauchi, F., T. Yoshikawa, S. Kaneno, H. Shibuya, and R. Takahashi (1987b) The chronic administration of dopamine antagonist and methamphetamine changed the $\left[{ }^{3} \mathrm{H}\right]$-cholecystokinin- 8 binding sites in the rat frontal cortex. Neuropeptides 10:221-225.

Gaudreau, P., R. Quirion, S. St-Pierre, and C. B. Pert (1983) Characterization and visualization of cholecystokinin receptors in rat brain using $\left[{ }^{3} \mathrm{H}\right]$ pentagastrin. Peptides 4: 755-762.

Gaudreau, P., S. St-Pierre, C. B. Pert, and R. Quirion (1985) Cholecystokinin receptors in mammalian brain: A comparative characterization and visualization. Ann. NY Acad. Sci. 448: 198-219.

Gaudreau, P., J. N. Crawley, and R. Quirion (1986) Effect of chronic haloperidol treatment on brain cholecystokinin receptors in rat. Soc. Neurosci. Abstr. 16: 230.12

Gilles, C., J. Lostra, and J. J. Vanderhaegen (1983) CCK nerve terminals in the rat striatal and limbic areas originate partly in the brain stem and partly in telencephalic structures. Life Sci. 32: 1683-1690.

Govoni, S., H. Y. T. Yang, A. Bosio, G. Pasinetti, and E. Costa (1982) Cholecystokinin and dopamine. Adv. Biochem. Psychopharmacol. 33: 437-444.

Grace, A. A., and B. S. Bunney (1980) Effects of baclofen on nigral dopaminergic cell activity following acute and chronic haloperidol treatment. Brain Res. Bull. 5(Suppl. 2): 537-543.

Grace, A. A., and B. S. Bunney (1986) Induction of depolarization block in midbrain dopamine neurons by repeated administration of haloperidol: Analysis using in vivo intracellular recording. J. Pharmacol. Exp. Ther. 238: 1092-1100.

Gysling, K., and M. Beinfeld (1984) Failure of chronic haloperidol treatment to alter levels of cholecystokinin in the rat brain striatum and olfactory tubercle-nucleus accumbens area. Neuropeptices 4:421423.

Haigler, H. J., and G. K. Aghajanian (1974) Lysergic acid diethylamide and serotonin: A comparison of effects on serotonergic neurons receiving a serotonergic input. J. Pharmacol. Exp. Ther. 168: 688-699.

Hays, S. E., M. C. Beinfeld, R. T. Jensen, F. K. Goodwin, and S. M. Paul (1980) Demonstration of a putative receptor site for cholecystokinin in rat brain. Neuropeptides $1: 53-62$.

Herkenham, M., and C. B. Pert (1982) Light microscopic localisation of brain opiate receptors: A general autoradiographic method which preserves tissue quality. J. Neurosci. 2: 1129-1149.

Hill, D. R., T. M. Shaw, and G. N. Woodruff (1987a) Species differences in the localization of peripheral type cholecystokinin receptors in rodent brain. Neurosci. Lett. 79: 286-289.
Ilill, D. R., N. J. Campbell, T. M. Shaw, and G. N. Woodruff (1987b) Autoradiographic localization and biochemical characterization of peripheral type CCK receptors in the rat CNS using highly selective nonpeptide CCK antagonists. J. Neurosci. 7: 2967-2976.

Hökfelt, T., J. F. Rehfeld, L. R. Skirboll, B. Ivemark, M. Goldstein, K. Marley, and O. Dann (1980a) Evidence for coexistence of dopamine and cholecystokinin in mesolimbic neurons. Nature 285: 476-478.

Hökfelt, T., L. R. Skirboll, J. F. Rehfeld, M. Goldstein, K. Marley, and O. Dann (1980b) A subpopulation of mesencephalic dopamine neurons projecting to limbic areas contains a cholecystokinin-like peptide: Evidence from immunohistochemistry combined with retrograde tracing. Neuroscience 5: 2093-2124.

Hommer, D. W., M. Palkovits, J. N. Crawley, S. M. Paul, and L. R. Skirboll (1985) Cholecystokinin-induced excitation in the substantia nigra: Evidence for peripheral and central components. J. Neurosci. 5: $1387-1392$.

Hu, X. T., and R. Y. Wang (1985) Denervation supersensitivity to cholecystokinin and dopamine in the rat nucleus accumbens: $\mathrm{Mi}-$ croiontophoretic studies. Soc. Neurosci. Abstr. 15: 217.7.

Innis, R. B., and S. H. Snyder (1980) Distinct cholecystokinin receptors in brain and pancreas. Proc. Natl. Acad. Sci. USA 77: 69176921.

Johnson, S. W., B. J. Hoffer, and R. Freedman (1986) Investigation of the failure of parenterally administered haloperidol to antagonize dopamine released from micropipettes in the caudate. J. Neurosci. 6 : $572-580$.

König, J. F. R., and R. A. Klippel (1963) The Rat Brain-A Stereotaxic Atlas of the Forebrain and Lower Parts of the Brain Stem, Williams \& Wilkins, Baltimore, MD.

Kuhr, W. G., J. C. Bigelow, and R. M. Wightman (1986) In vivo comparison of the regulation of releasable dopamine in the caudate nucleus and the nucleus accumbens of the rat brain. J. Neurosci. 6: 974-982.

Lin, C. W., and T. Miller (1985) Characterization of cholecystokinin receptor sites in guinea pig cortical membrane using [ $\left.{ }^{125} \mathrm{I}\right]$ Bolton Hunter-cholecystokinin octapeptide. J. Pharmacol. Exp. Ther. 232: $775-780$.

Louilot, A., A. Buda, F. Gonon, H. Simon, M. Le Moal, and J. F. Pujol (1985) Effect of haloperidol and sulpiride on dopamine metabolism in nucleus accumbens and olfactory tubercle: A study by in vivo voltammetry. Neuroscience $14: 775-782$.

Lundberg, J. M., A. Rudehill, A. Sollevil, E. Theodorsson-Norheim, and B. Hamberger (1986) Frequency- and reserpine dependent chemical coding of sympathetic transmission: Differential release of noradrenaline and neuropeptide $Y$ from pig spleen. Neurosci. Lett. 63: $96-100$

Mantyh, C. R., and P. W. Mantyh (1985) Differential localization of cholecystokinin- 8 binding sites in the rat vs. the guinea pig brain. Eur. J. Pharmacol. 113: 137-139.

Marley, P. D. P. C. Emson, and J. F. Rehfeld (1982) Effect of 6-hydroxydopamine lesions of the medial forebrain bundle on the distribution of cholecystokinin in rat forebrain. Brain Res. 252: 382-385.

Mishra, R. K. (1983) Modulation of dopamine receptors by peptide. Prog. Neuro-Psychopharmacol. Biol. Psychiatry 7: 437-442.

Moran, T. H., P. H. Robinson, M. S. Goldrich, and P. R. McHugh (1986) Two brain cholecystokinin receptors: Implications for behavioral actions. Brain Res. 362: 175-179.

Morin, M. P., P. de Marchi, J. Champagnat, J. J. Vanderhaegen, J. Rossier, and M. Denavit-Saubie (1983) Inhibitory effect of CCK octapeptide on neurons in the nucleus tractus solitarius. Brain Res. 265: 333-338.

Muller, P., and P. Seeman (1978) Dopaminergic supersensitivity after neuroleptics: Time-course and specificity. Psychopharmacology 60 . $1-11$.

Nair, N. P. V., and D. M. Bloom (1986) Cholecystokinin and schizophrenia. Prog. Brain Res. 65: 237-258

Nowak, J. L., S. Arbilla, A. M. Galzin, and S. Z. Langer (1983) Changes in sensitivity of release modulating dopamine autoreceptors after chronic treatment with haloperidol. J. Pharmacol. Exp. Ther. 226 : 558-564.

Nowycky, M. C., and R. H. Roth (1978) Dopaminergic neurons: Role of presynaptic receptors in the regulation of transmitter biosynthesis. Prog. Neuro-Psychopharmacol. 2: 139-158.

Parker, E. M., and L. X. Cubeddu (1985) Evidence for autoreceptor 
modulation of endogenous dopamine release from rabbit caudate nucleus in vitro. J. Pharmacol. Exp. Ther. 232: 495-500.

Pelaprat, D., J. M. Zajac, G. Gacel, C. Durieux, J. L. Morgat, A. Sasaki, and B. Roques (1985) [ $\left.{ }^{3} \mathrm{H}\right]$ Boc [Nle ${ }^{28.31}$ ] CCK 27-33, a new highly labelled ligand for CCK receptors: Binding on brain and pancreas. Life Sci. 37: 2483-2490.

Praissman, M., P. A. Martinez, C. F. Saladino, J. M. Berkowitz, A. W. Steggles, and J. A. Finkelstein (1983) Characterization of cholecystokinin binding sites in rat cerebral cortex using a ${ }^{125} \mathrm{I}$-CCK-8 probe resistant to degradation. J. Neurochem. 40:1406-1413.

Quirion, R., C. Csonka, P. Etienne, N. P. V. Nair, Y. Robitaille, and P. Gaudreau (1985) Autoradiographic localization of cholecystokinin receptors in human brain. Ann. NY Acad. Sci. 448: 624-626.

Rehfeld, J. F. (1978) Immunochemical studies of cholecystokinin. II. Distribution and molecular heterogeneity of cholecystokinin in the central nervous system and small intestine of man and dog. J. Biol. Chem. 253: 4022-4030.

Rogawski, M. A. (1982) Cholecystokinin octapeptide: Effects on the excitability of cultured spinal neurons. Peptides 3: 545-551.

Roth, R. H. (1984) CNS dopamine autoreceptors: Distribution, pharmacology and function. Ann. NY Acad. Sci. 430: 363-369.

Saito, A., H. Sankaran, I. D. Goldfine, and J. A. Williams (1980) Cholecystokinin receptors in the brain: Characterization and distribution. Science 208: 1155-1156.

Scatton, B., C. Garret, and L. Julou (1975) Acute and subacute effects on dopamine synthesis and release in the rat striatum. NaunynSchmiedeberg's Arch. Pharmacol. 289: 419-434.

Scatton, B., J. Glowinski, and L. Julou (1976) Dopamine metabolism in the mesolimbic and mesocortical dopaminergic systems after single or repeated administrations of neuroleptics. Brain Res. 109: 184-189.

Sekiguchi, R., and T. Moroji (1986) Á comparative study on characterization and distribution of cholecystokinin binding sites among the rat, mouse and guinea pig brain. Brain Res. 399: 271-281.

Severson, J. A., H. E. Robinson, and G. M. Simpson (1984) Neuroleptic-induced striatal dopamine receptor supersensitivity in mice: Relationship to dose and drug. Psychopharmacology 84: 115-119.

Skirboll, L. R., and B. S. Bunney (1979) The effects of acute and chronic haloperidol treatment on spontaneously firing neurons in the caudate nucleus of the rat. Life Sci. 25: 1419-1434.

Skirboll, L. R., A. A. Grace, D. W. Hommer, J. F. Rehfeld, M. Goldstein, T. Hökfelt, and B. S. Bunney (1981) Peptide-monoamine coexistence: Studies on the actions of cholecystokinin-like peptide on the electrical activity of midbrain dopamine neurons. Neuroscience 6: 2111-2124.

Somjen, G. G., P. Zarzecki, and D. Blake (1976) Persistence of nigrostriate transmission and dopamine-induced inhibition of caudate nucleus neurons in the presence of extrapyramidal dysfunction caused by haloperidol in cats. Soc. Neurosci. Abstr. 2: 205.

Studler, J. M., H. Simon, F. Cesselin, J. C. Legrand, J. Glowinski, and J. P. Tassin (1981) Biochemical investigation on the localization of the cholecystokinin octapeptide in dopaminergic neurons originating from the VTA of the rat. Neuropeptides 2: 131-139.

Vanderhaegen, J. J., J. C. Signeau, and W. Gepts (1975) New peptide in the vertebrate CNS reacting with gastrin antibodies. Nature 221 : 557-559.

Van Dijk, A., J. G. Richards, A. Trzeciak, D. Gillesen, and H. Mohler (1984) Cholecystokinin receptors: Biochemical demonstration and autoradiographical localization in rat brain and pancreas using $\left[{ }^{3} \mathrm{H}\right]$ cholecystokinin-8 as radioligand. J. Neurosci. 4: 1021-1033.

Vickroy, T. W., B. R. Bianchi, J. F. Kerwin, H. Kopecka, and A. M. Nazdan (1988) Evidence that type A CCK receptors facilitate dopamine efflux in rat brain. Eur. J. Pharamacol. 152: 371-372.

Wang, R. Y., and X. T. Hu (1986) Does cholecystokinin potentiate dopamine action in the nucleus accumbens? Brain Res. 380: 363367.

Wennogle, L. P., D. J. Steel, and B. Petrack (1985) Characterization of central cholecystokinin receptors using a radioiodinated octapeptide probe. Life Sci. 36: 1485-1492.

White, F. J., and R. Y. Wang (1983) Comparison of the effects of chronic haloperidol treatment of $\mathrm{A} 9$ and $\mathrm{A} 10$ dopamine neurons in the rat. Life Sci. 32: 983-993.

White, F. J., and R. Y. Wang (1984) Interactions of cholecystokinin and dopamine on nucleus accumbens neurons. Brain Res. 300: 161166.

Yang, C. R., and G. J. Mogenson (1986) Dopamine enhances terminal excitability of hippocampal-accumbens neurons via D2 receptor: Role of dopamine in presynaptic inhibition. J. Neurosci. 6: 2470-2478.

Zarbin, M. A., R. B. Innis, J. R. Wamsley, S. H. Snyder, and M. J. Kuhar (1983) Autoradiographic localization of cholecystokinin receptors in rodent brain. J. Neurosci. 3: 877-906.

Zarzecki, P., D. J. Blake, and G. Somjen (1977) Neurological disturbances, nigrostriate synapses, and iontophoretic dopamine and apomorphine after haloperidol. Exp. Neurol. 57: 956-970. 